\title{
Brexit: Australian Perspectives on International Trade and Customs Operations
}

\author{
ROBERTO BERGAMI \\ Victoria University \\ The University of South Bohemia \\ Roberto.Bergami@vu.edu.au
}

\begin{abstract}
The decision made by a slight majority of voters in the UK to leave the EU, based on a non-binding referendum, sent initial shockwaves across the globe. The separation of the UK from the EU is still a process in the making, as there is no certainty about the negotiation approach the UK or the EU will adopt on the terms of the so called Brexit. This paper seeks to outline the major aspects of market access for the international trade of goods between the UK and the EU and the impact and opportunities for Australia, noting the comparatively greater importance of the EU 27 to Australia. The paper concludes that the economic interdependence between the UK and the EU warrants a winwin solution, despite the many as yet unknown challenges that lie ahead.
\end{abstract}

Key words: Brexit, customs regulations, free trade agreements, international supply chain security, rules of origin, tariffs

\section{Introduction}

On 23 June 2016 a non-legally binding referendum ${ }^{1}$, dubbed Brexit, was held in the United Kingdom to gauge popular (?) feeling in relation to continued membership of the EU. To the surprise of most commentators and experts, the resulting vote on Brexit was a slight majority $\left(51.9 \%\right.$ from a national voting turnout of $72.2 \%^{2}$ ) in favour a 'No' vote, that is, the severing of ties with the EU by ceasing to remain a member of that union.

The paper firstly provides a selected chronological background, outlining the main reasons that led to the Brexit process. This is followed by a discussion about possible consequences on particular likely aspects related to international trade issues, and their relevance to Australia, before reaching the conclusion.

To date, the full implications of the decision to leave the EU are unknown, simply because this process has no historical precedent and there is no certainty about what model may apply to such a separation. Given the recency of this event, a body of academic literature on Brexit has not yet had a chance to develop. Consequently, the

\footnotetext{
${ }^{1}$ S. Shuster, 'Europe’s Crisis of Faith', Time, July 11-18, 2016, pp. 12-16.

2 'Up to the minute results for the 2016 EU Referendum from BBC News', 23 June 2016,

http://www.bbc.com/news/politics/eu_referendum/results, accessed 20 November, 2016.
} 
paper does not provide a formal literature review, preferring to quote sources directly as they are relevant to the topics of discussion.

\section{Background to Brexit}

On 18-19 February 2016, at an EU summit in Brussels, the then UK Prime Minister, David Cameron, successfully argued for a 'reformed EU'. The main issues under consideration at that time were:

- A cut in work and child benefits for EU migrants to Britain;

- An exemption for Britain from the EU treaty goal of "ever-closer union"; and

- An agreement to protect countries not in the euro from decisions of those in the single currency that they objected to. 3

The reasons for Cameron seeking the above concessions came from a growing antiinstitution populist movement that perceived a loss of 'control' over local issues. "Western societies are witnessing a growing disaffection with democratic institutions" 4 and this leads to the politics of 'us' and 'them' as enemies, creating and antagonistic situation.

What is at stake is how to establish the us/them discrimination that is compatible with pluralist democracy. In the realm of politics, this presupposes that the 'other' is no longer seen as an enemy to be destroyed, but somebody with whose ideas we are going to struggle but whose right to defend those ideas we will not put into question. ${ }^{5}$

Brexit was such a process where both the yes and no campaigns were able to argue their case accordingly. There was influence from growing populism, during the referendum campaign. Populism "is, quite simply, a way of constructing the political". ${ }^{6}$ Populism "simplifies the political space, replacing a complex set of difference and determinations by a stark dichotomy whose two poles are necessarily imprecise". 7 The dichotomy was whether the UK should leave the EU or not.

The perceptions created by the leave campaign included the loss of UK sovereignty, as a result of being bound by 'external' EU legislation and regulation, and the possible influx of migrants resulting from the Syrian conflict, with a detrimental effect on living conditions for UK citizens. It seems, however, the Syrian conflict has had little impact as

Britain has remained largely sealed off from the refugee crisis that has rocked much of the rest of Europe for the past year. Protected by geography and its status outside the passport-free Schengen zone, it took only a fraction of the asylum seekers who arrived at Europe's southern shores last year. This reality has not prevented wildly-televised images of migrants and refugees streaming through the Balkans from taking root in the

\footnotetext{
3 The Economist, 'David Cameron Strikes a European Union Deal', February 20, 2016, http://www.economist.com/news/britain/21693324-britains-out-referendum-will-be-held-june-23rd-davidcameron-strikes-european-union-deal, accessed on 20 November, 2016.

4 C. Mouffe, 'Deliberative Democracy or Agonistic Pluralism', Social Research, Vol. 66, No. 3, 1999 , p. 746.

5 Ibid, p. 755

${ }^{6}$ E. Laclau, On Populist Reason, London: Verso, 2005, p. xi.

7 Ibid, p. 18.
} 
Bergami, ANZJES 9(1)

public imagination and becoming associated with "uncontrolled" immigration to the UK - one of the biggest issues in the run-up to Thursday's EU referendum. ${ }^{8}$

In an effort to boost the votes for the leave campaign, the UK Independence Party (UKIP) used photographs of hundreds of refugees at the Croatian-Slovenian border with a poster prominently featuring the words "BREAKING POINT The EU has failed us all". 9 Politically, the UKIP was capitalising on the creation of a perception that suited its own purposes, regardless of how facts were being used.

Cameron needed to quell opposing political views, especially from within his party, as part of his push for re-election, and he sought to do so by striking a new deal with the EU.

On 20 February 2016, Cameron announced a referendum, to be held on 23 June, on whether the UK should remain a member of the EU or not, based on the 'new deal' (the concessions just won). In the event of a negative referendum vote outcome however, the EU concessions would be withdrawn. Importantly, the referendum was non-legally binding. Sceptics may well argue that Cameron's motives were just as populist as the movement he was trying to quell.

It is generally accepted that the vast majority of commentators and experts were expecting a 'Yes' vote, meaning the status quo in EU membership, albeit with the concessions Cameron won, as these were the raison d'être for remaining in the EU. Indeed

... exactly a week before the referendum, the noisy, rancorous and often misleading campaign for the country to leave the E.U. nearly fell apart. Center-left lawmaker Jo Cox, one of the most charismatic advocates for the U.K. to remain in the E.U., was murdered on the streets of her electoral district. The man charged with shooting and stabbing her to death, Thomas Mair, would later say in court: "My name is death to traitors, freedom for Britain." Many hoped that Cox's tragic killing would at least serve as a wake-up call for Britain. As the polls opened on June 23, most pundits, academics, bookmakers and politicians were confident that economic good sense, if not the more abstract ideals that hold Europe together, would prevail over the fearful calls to retreat behind the English Channel in the face of migration and globalization. ${ }^{10}$

Cameron gambled his political future on the concessions and a nation united in retaining membership of the EU, but alas this was not the case. As history has it, the majority vote was a 'No', ending Cameron's prime-ministership the very next day as, shell-shocked by the result, he announced his resignation, adding at the time that the will of the British people must be respected - although clearly he was not going to be involved in that process. The immediate power vacuum created by the swift departure of Cameron created an initial lack of direction. The somewhat acrimonious 'behind the scene' struggle for leadership is beyond the scope of this paper, consequently no detailed comments are offered in this respect. However, the leadership struggle was short lived, as within three weeks following, a new leader was appointed. Teresa May took office as Prime Minister on 13 July, soon after confirming the will of the people

\footnotetext{
${ }^{8}$ K. Siegfried, ‘What Does Brexit Mean for Refugees?', IRIN, 27 June 2016, http://www.irinnews.org/analysis/2016/o6/27/what-does-brexit-mean-refugees, accessed on 27 February 2017. 9 K Siegfried, 'What Does Brexit Mean for Refugees?'op.cit.

10 S. Shuster, 'Europe's Crisis of Faith', op.cit., p. 12.
} 
would be abided to "declaring that Brexit means Brexit". ${ }^{11}$ In order for the UK to leave the EU, it must invoke Article 50 of the Lisbon Treaty. Article 50.1 states "Any Member State may decide to withdraw from the Union in accordance with its own constitutional requirements". Curiously, the political dogma has remained that the UK must leave the EU based on a non-legally binding preference, yet the current government does not wish to have a political vote in parliament - it seems like a case of selective democracy. To add to the current government woes, the UK government lost a High Court case where a panel led by the Lord Chief Justice John Thomas ruled that the Prime Minister does not have the power to unilaterally trigger Article 50, meaning this must be done through parliament. ${ }^{12}$ The UK government is appealing that decision through a Supreme Court challenge, with an emergency hearing set for December 7 and 8. The Supreme Court judgment given on 24 January $2017^{13}$ upheld the High Court decision, meaning an Act of the UK Parliament is required before formal notification of withdrawal under Article 50 is given to the Council of the European Union. In response, the European Union (Notification of Withdrawal) Bill 2017 was formally introduced in the UK Parliament on 26 January 2017 and at the time of writing it was progressing through parliamentary processes. Consequently, it is not possible to make additional remarks at this stage, other than to say confusion continues to reign in what appears to be a most disorderly Brexit process, one caught in a vacuum undermining confidence in the business environment. Indeed with the current paralysis, it may well be asked: Is there a Brexit process? The government claims there is, but it needs to play its cards close to its chest, insisting "that to give more clarity over its objectives would be to tie its hands in Brussels". ${ }^{14}$ Sceptics may argue that this demonstrates there is no plan, just the government's 'spin doctors' creating an appearance of one, as after all secrecy is a powerful weapon to counteract open discussion. If there is indeed a plan, it appears this has not featured in government so far, with reports that "the deterioration in public finances will cumulate to about $£ 100 b n " 15$ as a result of Brexit. Even from outside Europe, the belief is that "Brexit is going to impair growth for the foreseeable future". ${ }^{16}$

The immediate result from the Brexit vote drew ire from Scotland. On 18 September $2014,62 \%$ of the Scottish people voted in a referendum to remain in the UK, largely because 'going at it alone' would mean they would no longer automatically be part of the EU. Whilst remaining part of the UK was not necessarily the main reason for a 'remain' vote, the loss of EU membership was definitely not favoured by the Scots. Brexit may well cause another Scottish referendum, with all the challenges that may ensue if the decision is to leave the UK in order to remain in the EU.

Adding to the plight of the UK as its own 'union of nations', is the question of Ireland - geographically one nation, but politically two. The fragile peace in Northern Ireland may be unable to withstand such a separation, raising prospects of a resurgence of nationalist idealism and a return to the days of an active IRA - a rather gloomy

${ }^{11}$ A. Applebaum, 'Brexit paralysis will feed witch hunts', The Age, 3 December, 2016, p.18.

${ }^{12}$ In the High Court of Justice Queen's Bench Divisional Court, the Queen on the application of (1) Gina Miller \&

(2) Deir Tozetti Dos Santos and the Secretary of State for exiting the European Union (1) Grahame Pigney \& others (2) AB, KK, PR and Children Interested Parties Mr George Birnie \& Others, Neutral Citation Number: [2016] EWHC 2768 (Admin) Case No: $\mathrm{CO} / 3809 / 2016$ and CO/3281/2016.

${ }^{13}$ The Supreme Court, R (on the application of Miller and another) v Secretary of State for Exiting the European Union [2017] UKSC 5 On appeals from: [2016] EWHC 2768 (Admin) and [2016] NIQB 85.

${ }_{14}$ The Economist, 'Brexit and Parliament: Questions of Sovereignty', November 12, 2016, p. 50.

${ }^{15}$ C. Giles, 'The UK Faces £10obn 'Brexit' Budget Hole as EU Exit Vote Hits Growth Forecast', Financial Times, 17

November 2016, p. 1

${ }^{16}$ J. Kuzeljevich, "Brexit for Shippers', Canadian Shipper, September/October, 2016, p. 24 
prospect. On leaving the EU, will there be a virtual 'Dublin Wall' (a 'new era' Berlin Wall), even though Northern Ireland voted $55.8 \%$ to remain in the EU17? It has been noted by some commentators that "Sinn Fein might argue that such a border would invalidate the British-Irish Agreement Act which established devolved government at Stormont, and renew its campaign for a united Ireland". ${ }^{18}$ Brexit may well have a number of unintended ramifications, with little apparent thought given to these by the ruling UK government. Perhaps this may be partly explained by the fact that since a 'No' vote was unexpected, no prior plans were formulated simply because the government in office did not believe these were going to be necessary.

Having provided some background to Brexit, the next section turns to a discussion of selected potential Brexit challenges, limited to aspects of international trade practices, that is, the likely impact on market access for export and import business. As appropriate, comments on likely impacts on Australia's international trade relation with the UK (more or less 'united', as the case may be) are provided. It should be noted that numerous other aspects of Brexit challenges, including EU farming subsidies, funding for university research, or the possible relocation of the EMEA or the "UK's financial institutions benefits from passport rights that allows them to provide their services through the Single market"19 are beyond the scope of this paper.

\section{UK trade patterns with the EU and post Brexit arrangement options}

A summary of the UK's major bilateral international trade flows for 2015 with its ten major trading partners is provided at Figure 1. It can be observed that whilst the UK enjoyed trade surpluses with some of its trading partners, overall it appears the UK is a net importer. A significant proportion of UK's export and import trade is conducted with EU member states.

There is a high level of interdependence on export and import activity with other EU member states, as these represent seven out of the top ten trading UK partners. It should also be noted that, according to the data in Figure 1, the UK appears to be a net importer with major EU member states' trading partners.

${ }^{17}$ Australian Government Department of Foreign Affairs and Trade, 'UK Decision to Leave the EU - Brexit', 12 October 2016, http://dfat.gov.au/geo/united-kingdom/Pages/brexit.aspx, accessed on 20 November, 2016. ${ }^{18} \mathrm{~J}$. Springford and S. Tilford, 'Twelve Things You Need to Know About Brexit', Prospect, January 2016, p. 56. 19 J. Miethe and D. Pothier, 'Brexit: What's at Stake for the Financial Sector', DIW Economics Bulletin, 31, 2016, p.364. 


\begin{tabular}{|l|r|r|r|r|}
\hline $\begin{array}{c}\text { Major Trading } \\
\text { Partners }\end{array}$ & $\begin{array}{c}\text { Exported } \\
\text { value (2015) }\end{array}$ & $\begin{array}{c}\text { Percentage of } \\
\text { UK world } \\
\text { trade }\end{array}$ & $\begin{array}{c}\text { Imported } \\
\text { value } \\
\text { (2015) }\end{array}$ & $\begin{array}{c}\text { Percentage of } \\
\text { UK world } \\
\text { trade }\end{array}$ \\
\hline USA & $69,325,414$ & $14.88 \%$ & 58066468 & $9.23 \%$ \\
\hline Germany & $46,438,990$ & $9.97 \%$ & 94074455 & $14.95 \%$ \\
\hline Switzerland & $34,022,548$ & $7.30 \%$ & 10226346 & $1.63 \%$ \\
\hline China & $27,623,635$ & $5.93 \%$ & 62979629 & $10.01 \%$ \\
\hline France & $27,255,625$ & $5.85 \%$ & 38620477 & $6.14 \%$ \\
\hline Netherlands & $26,510,351$ & $5.69 \%$ & 47289939 & $7.52 \%$ \\
\hline Ireland & $25,472,101$ & $5.47 \%$ & 19167537 & $3.05 \%$ \\
\hline Belgium & $17,695,481$ & $3.80 \%$ & 31387028 & $4.99 \%$ \\
\hline Spain & $13,535,635$ & $2.91 \%$ & 21542554 & $3.42 \%$ \\
\hline Italy & $12,861,743$ & $2.76 \%$ & 24976793 & $3.97 \%$ \\
\hline EU members & $169,769,926$ & $36.44 \%$ & 277058783 & $44.03 \%$ \\
\hline
\end{tabular}

Figure 1: UK's Major Bilateral International Trade Flows in 2015 - USD thousands ${ }^{20}$

These relationships have potentially significant economic repercussions, given the current single market structure operating in the EU. Whilst it may be politically expedient for the EU to 'excise' the UK form its current Free Trade Agreements (FTA), so as to minimise the impact of Brexit on free trade between the other $27 \mathrm{EU}$ economies and its external partners, re-negotiating new trade arrangements between the UK and the EU may not be so simple. The removal of the UK from current FTA agreements ought not be difficult, as after all, FTAs are periodically renegotiated and it would simply be a matter of diplomatic agreement to make variations, although such arrangements are still subject to ratification by local governance structures and processes. As to what form of a re-negotiated trade deal the UK may pursue, at this stage it is pure conjecture. However, it has been suggested ${ }^{21}$ five options are available post the invocation of Article 50 of the Lisbon Treaty, and these are discussed below.

1. WTO membership alone. This is the default solution should there be no trade agreement within two years of triggering Article 50 of the Lisbon Treaty. This option would not allow for any integration between the UK and the EU, placing it at considerable disadvantage. Tariffs would apply consistent with the same treatment afforded to non-EU member states. This would be the least preferred option for the UK, as it would be able to enjoy at most MFN status with no preferential treatment unless separate arrangements were put in place, as outlined below. Transactions are likely to become more complex as origin certification and compliance will assume greater importance. Origin certification processes are conducted via third parties (typically Chambers of Commerce or equivalent bodies) adding another layer of complexity, taking more time to complete resulting in higher costs of doing business across borders.

${ }^{20}$ Data obtained from ITC Trade Map, http://www.trademap.org/Country_SelProductCountry_TS.aspx, accessed 25 November, 2016. These data have been calculated by ITS based on UN COMTRADE statistics.

${ }^{21}$ R. Munro and H. White, 'Brexit Brief: Options for the UK'S Future Trade Relationship with the EU', Institute for Government, 6 July, 2016,

http://www.instituteforgovernment.org.uk/sites/default/files/publications/brexit $\% 20$ options $\% 20 \mathrm{a} 3 \% 20$ november \%20update.pdf, Accessed 27 November 2016. 
Bergami, ANZJES 9(1)

2. The European Economic Area (EEA). The 'Norway model'. This would allow the UK significant access to the EU Single Market for industrial goods, with limitations imposed on agricultural goods and fisheries produce. The UK would also "likely be obliged to accept EU regulations and free movement of people and make a budgetary contribution. Obtaining membership of the Single Market without meeting these conditions would be unprecedented". ${ }^{22}$ Given that movement of people was one of the Brexit issues, it is difficult to see this option as one of the most favoured approaches. Under the EEA model, the UK would not be a member of the EU Customs Union, consequently, customs checks would be required between the UK and EU member states. This model, like options 3 and 4 below, would accrue significant costs to the UK economy, adding transactional complexity. Additional documentation certifying origin may be required as this is a common FTA condition. It may be successfully argued that as the UK and the EU have enough trust in each other, self-certification may be allowed, thus eliminating the additional cost and time required to obtain independent third party origin certification. Rules of Origin, one of the cornerstones of any FTA, would need to be agreed to and their likely impacts are discussed later in the paper. Although the UK is a re-exporter of goods, this is not a critical consideration. In fact, in $2014^{23}$, the only significant re-exports from the UK to Europe were to Switzerland (USD 1.2 Billion) and Norway (USD 529 Million) - neither of these states are EU members.

Whilst there would be an obligation for the UK to comply with Single Market rules, the UK would no longer be subject to ECJ rulings. The UK would have a right to be consulted over EU legislation (although with limited influence), but retain the right to negotiate its own agreements with non-EU third parties.

3. European Free Trade Agreement (EFTA) supplemented by other bilateral agreements. The 'Switzerland model'. This would give the UK access to the EU Single Market for all non-agricultural items. Additional bilateral deals would be required to gain additional access to other areas of the EU Single Market. Free people movement would most likely be a part of this arrangement, making for a less palatable option as this was one of the Brexit issues. Like the Norway model, EFTA would not make the UK a member of the EU Customs Union, consequently customs checks would be required between the UK and EU member states, accruing significant costs to the economy and adding transactional complexity, as outlined at option 2 above. Whilst there would be an obligation for the UK to comply with Single Market rules, the UK would no longer be subject to ECJ rulings, would lose any influence over EU legislation, but retain the right to negotiate its own agreements with non-EU third parties.

According to Ottaviano et al. the estimated cost of leaving the EU and joining EFTA would lead to a "fall in trade with EU members [and] will reduce the UK's overall trade by $12.6 \% " 24$.

\footnotetext{
${ }^{22}$ C. Emmerson, P. Johnson and I Mitchell, The EU Single Market: The Value of Membership Versus Access to the UK, London: Institute for Fiscal Studies, 2016, p.2.

23 Data obtained from ITC Trade Map, op.cit.

${ }^{24}$ G. Ottaviano, J.P. Pessoa, T. Sampson, and J. van Reenen, John, (2014), 'The costs and benefits of leaving the EU', No 472, CFS Working Paper Series, Center for Financial Studies (CFS),

https://www.econstor.eu/bitstream/10419/102649/1/798138858.pdf, accessed 25 November, 2016, p. 10.
} 
4. A Free Trade Agreement different to EFTA. This would be similar to those enjoyed by Singapore or South Korea, or the yet to be implemented CETA, although some quota restrictions are likely to apply to certain products. Depending on the certification of origin, transactional complexity as outlined in option 2 above may ensue, with potentially added documentation costs and extended supply times. Additional costs would be incurred by exporters in obtaining origin certification. The additional documentary requirements will inevitably lengthen the supply chain, as exporters will need to produce additional documentation and provide this to certification authorities prior to consignments being exported. As Certificates of Origin are not issued free of charge exporters will incur extra costs that will be passed on to buyers.

5. Membership of the EU Customs Union. The 'Turkey model'. Under this arrangement, the UK would be able to access the EU market for industrial and processed agricultural goods, with no duties, tariffs or quotas. However, raw agricultural goods are excluded from this arrangement. This option does not include freedom of people movement - a contentious issue in Brexit however, the UK would still need to abide by EU rules on matters such as product and environmental rules, as well as competition.

In summary it seems that Brexit may deliver selective freedoms. There is freedom to independently negotiate other trade arrangements outside the EU, but Single Market access would demand the UK to be fully compliant, without having the option to formally influence these processes under almost all of the options above. It is difficult to see what the UK would gain in reality, other than a 'perception of freedom', as the UK economy is too economically interdependent with the EU to benefit from an 'acrimonious divorce'.

\section{Brexit and Australia}

Australia's 2015 world ranking was number 19 for exports and number 14 for imports 25 . A summary of trade between Australia and the UK is provided at Figure 2, where it can be observed that approximately $2 \%$ of bilateral trade occurs between these two nations.

\begin{tabular}{|l|c|c|c|}
\cline { 2 - 4 } \multicolumn{1}{c|}{} & AUD Millions & $\begin{array}{c}\text { Total } \\
\text { share }\end{array}$ & Rank \\
\hline Exports to United Kingdom & 3,788 & $1.50 \%$ & 13 \\
\hline Imports from United Kingdom & 7,137 & $2.60 \%$ & 16 \\
\hline Total merchandise trade (exports + imports) & 10,925 & $2.10 \%$ & 13 \\
\hline
\end{tabular}

Figure 2: Australia's trade and investment relationship with United Kingdom (2015) ${ }^{26}$

In order to obtain a better understanding of the trade links, the major export and export items are shown at Figure 3. It can observed that, not unexpectedly, minerals are the largest Australian exports to the UK, and the world's larger mining concerns operating in Australia (BHP Billiton and Rio Tinto) already have some form of UK ownership. The UK is a prominent buyer of Australian wine. Although a weakened

25 World Trade Organisation, 'World Trade Statistical; Review', , 2016,

https://www.wto.org/english/res_e/statis_e/wts2016_e/wts16_chap9_e.htm, accessed 27 Fberuary, 2017.

${ }_{26}$ Australian Government, Department of Foreign Affairs and Trade, 'UK Fact Sheet', 12 October, 2016,

http://dfat.gov.au/trade/resources/Documents/uk.pdf, accessed 25 November, 2016. 
pound will place added pressure on prices of imported Australian wine, already facing pressure from South American competitors. ${ }^{27}$ The UK will continue to be an important market for beer, although the acquisition of Carlton and United Breweries by SA Miller means the Australian beer business is increasingly part of multinational empires and subject to their global strategic decisions in terms of market supply.

\begin{tabular}{|l|c|l|c|}
\hline $\begin{array}{c}\text { Major Australian } \\
\text { exports to the UK }\end{array}$ & $\begin{array}{c}\text { AUD } \\
\text { Millions }\end{array}$ & Major UK exports to Australia & $\begin{array}{c}\text { AUD } \\
\text { Millions }\end{array}$ \\
\hline Lead & 467 & Passenger motor vehicles & 1,300 \\
\hline Gold & 424 & Medicaments (incl veterinary) & 462 \\
\hline Alcoholic beverages & 387 & $\begin{array}{l}\text { Pharm products (excl } \\
\text { medicaments) }\end{array}$ & 315 \\
\hline Pearls \& gems & 359 & Printed matter & 271 \\
\hline
\end{tabular}

Figure 3: Main export and import items traded between Australia and the UK (2015) ${ }^{\mathbf{2 8}}$

The major UK exports to Australia are passenger motor vehicles, followed by medicaments and pharmaceutical products and then printed matter. The Australian market for passenger motor vehicles may provide additional opportunities given the imminent demise of the Australian automotive industry. In 2017 Toyota, the last remaining local manufacturer, will cease its operations, meaning all passenger motor vehicles in Australia will be imported in the future. To date the majority of Australian market demand for passenger motor vehicles has been satisfied by Asian manufacturers. There may also be opportunities for Australian automotive suppliers to become part of a global network and opportunities may arise in the UK in such respect. However, Brexit may have unintended consequences for the UK automotive sector, because of its high integration with the EU and "with 50-60\% of car components typically imported, supply chain costs could rise sharply" 29 .

The UK is a significant player in global pharmaceutical markets and this is reflected in the trade figures. Australia's strength in the pharmaceutical area is in innovation and discovery and not in manufacturing. Most of the Australian pharmaceutical market is already owned by multinational companies with some UK owned enterprises, such as GSK, having long standing manufacturing and distribution operations in Australia.

The Australian printed matter market is not large and comparatively expensive, and it is expected that demand for imports will continue steadily in the foreseeable future, despite some publications moving to electronic formats.

Australia's current trade focus is in the Asia-Pacific basin. Most of Australia's FTAs are bilateral with Asian nations, with one regional overlapping FTA, binding Australia New Zealand and the ASEAN nations (AANZFTA). Australia currently has bilateral agreements with Singapore (SAFTA), Thailand (TAFTA), Malaysia (MAFTA) and New Zealand (ANZCERTA). Each of these nations are also bound by the concurrent AANZFTA, so in these cases, exporters and importers may choose under which FTA they operate, as different benefits relate to origin determination and tariffs/quotas depending on the agreement chosen.

27 A. Catchpole, 'Costing Brexit', Drinks Wholesaler, August, 2016, p. 6.

${ }^{28}$ Australian Government, Department of Foreign Affairs and Trade, 'UK Fact Sheet', op. cit.

29 C. Ludwig, 'Brexit Shock Waves in the Supply Chain', Automotive Logistics, July-September, 2016, p. 8. 
To date, no FTA exists with the EU, although the process for a comprehensive FTA was commenced in November 2015. An EU FTA should be a more attractive proposition for Australia, as there is greater potential with the remaining $27 \mathrm{EU}$ member states. To illustrate further, in terms of merchandise trade, between the period 2014-2015 the EU took "4.9\% of Australian exports (UK 1.4\%), and provided 16.4\% of Australian imports (UK 2.3\%)".30 A free trade agreement between Australia and the UK may therefore deliver much less than one with the EU in respect of trade in physical goods, although opportunities may exist for investment and services, but these aspects are beyond the scope of this paper, so these will not be considered further.

An agreement with the UK may be a complicated pursuit in any case, as there is uncertainty over Scotland's future separationist intentions and also the Irish consideration.

The issues related to FTA of interest to this paper are the practical aspects and impact on export and import transactions as these affect costs and prices for traders. The next section considers security related aspects of international supply chains and what UK customs operation changes may be needed.

\section{Brexit and international supply chain security}

The horrific events of $9 / 11$ forced tremendous changes in international supply chain security. The US reacted quickly to roll out a voluntary security mechanism - the Customs Trade Partnership Against Terrorism (CT-PAT launched in November 2001). Members of the CT-PAT initiative are rewarded with less customs intervention, resulting in lower business costs, faster clearance procedures and a quicker supply chain. However, these initiatives only work where all parties involved in the supply chain are security compliant and members of the program. Securing the international supply chain, by necessity, affects trading partners in other nations because both the outwards as well as the inwards movements must be secured, otherwise there is no whole-of-chain control. CT-PAT was the approach broadly followed by the EU in developing its supply chain security program - the Authorised Economic Operator (AEO) launched in 2008. Both CT-PAT and the AEO enjoy mutual recognition. Australia recently launched its own supply chain security program - the Trusted Trader. Whilst these programs enjoy mutual recognition, their development and implementation is a time consuming and costly exercise for both governments and enterprise. Where would Brexit place the UK in terms of the AEO? It would be in the UK's best interest to devise a means by which it could obtain postBrexit supply chain security mutual recognition. As a current EU member the UK should already have AEO 'status' so perhaps the negotiations ought not be difficult. It would be in the best interest of the EU 27 as well as the UK to have strong security measures, especially given recent terrorist events in continental Europe. Developing a new set of processes is both time consuming and expensive for governments as well as private enterprise, so hopefully, without compromising security measure, logic and economic rationale will prevail on this issue.

Apart from security consideration, the customs processes may also be impacted by Brexit, and aspects of these are considered next.

${ }^{30}$ D. McDougall, 'Australia and Brexit: Déjà vu All Over Again?', The Round Table, Vol. 105, No. 5, October 2016, p. 562. 


\section{Brexit and customs operations}

The UK customs processing data for 2015 is summarised at Figure 5 .

\begin{tabular}{|l|r|}
\hline Data Item & 2015 Data \\
\hline Total number of movement declarations processed & $86.83 \mathrm{M}$ \\
\hline Percentage of transaction processed electronically & $99 \%$ \\
\hline Percentage of traffic cleared without customs clearance interventions & $96 \%$ \\
\hline Import entries & $70.51 \mathrm{M}$ \\
\hline Export entries & $7.08 \mathrm{M}$ \\
\hline
\end{tabular}

Figure 4: Volume of Transactions Processed by UK Customs in $2015^{31}$

It can be observed from Figure 4 that import entries were approximately 10 times those of export entries. This underscores the importance of imports to the UK economy, and that is also corroborated by the fact that the UK is a net importer. This is a significant concern depending on what sort of post-Brexit arrangements may be put in place. If the UK does not become a member of the EU Customs Union, it would need to operate under an FTA arrangement of some sort. One of the main principles of FTA is the question of origin. FTA provide preferential treatment to signatory nations, but only for goods that originate from those nations, consequently, third party goods are not afforded preferential treatment. Rules of Origin are used to "determine whether a good has been produced within a member country, in which case it is exempt from tariffs [fully or partially] under the FTA". ${ }^{2}$ Whilst it may be easy to apply rules of origin for primary products such as minerals, or vegetables, manufactured goods these days routinely incorporate items from various sources and determining the minimum content for origin purposes is not as easy as it seems. For example, FTAs Australia has negotiated include origin determination clauses that encompass minimum content and changes in tariff classification. What may be even more complex is a regional agreement, such as AANZFTA, where origin accumulation is possible to derive regional rather than local origin. This could be the model in operation in a EU-UK FTA, where the EU is a bloc or region, and so long as the majority of the components are from the EU, origin is assigned accordingly. Of course agreeing to the minimum content is not as clear cut as it may seem. Typically, Australia's bilateral FTAs have a 50\% content clause, but in the AANZFTA this varies and can be as low as $35 \%$ for some items. Given the cumulative nature of this FTA, component traceability and certification assumed greater importance. In the postBrexit scenario, enforcing the rules of origin may

mean customs check of some kind between the EU and the UK even in an FTA. These could be minimal if electronic documentation can be used but they would give French customs at Calais the right to inspect UK trucks to ensure the RoOs [Rules of Origin] are satisfied. All of this adds cost, delay and uncertainty to the trading relationship. ${ }^{33}$

Borders across Europe are, of course, not new and still in existence not long ago, as was the case for Ireland. In fact, the last customs post did not come down until $1993^{34}$, twenty years after the UK and Ireland acceded to the EEC (the former

${ }^{31}$ M. Walton, personal Correspondence, 7 December 2016.

${ }^{2}$ P. Holmes, J. Rollo and L.A. Walters, 'Negotiating the UK's Post-Brexit Trade Arrangements', National Institute economic Review, No. 238, November , 20916, p. R24.

33 Ibid.

34 R. D. Edwards, 'British exit, Irish wound', Prospect, December 2016, p. 28. 
structure for what is now the EU). Setting up border posts may open old wounds and create its own security crisis and could easily result, as it has in the past, in long queues, the need for physical checks of cargo and additional documentation because this would be crossing foreign borders.

In the absence of a total electronic solution for customs clearance in an FTA-like situation, additional customs officers would need to be employed at a greater cost both in the UK and the EU, unless these processes were 'outsourced' to logistics providers, along the same lines the Australian authorities have done with parts of the biosecurity clearance process. Under these arrangements, a co-regulatory scheme is in place, where suitably qualified customs brokers, having successfully completed specific training are authorised to process biosecurity data as part of the customs clearance process. The net result of this is a shift of work from the public to the private sector. It does not necessarily mean the cost of doing business has decreased, but additional flexibility has been built into the process, as logistics providers offer $24 / 7$ services, and this is not always the case with public officials.

\section{Conclusion}

Whilst the UK is an important economic power in the EU, it is doubtful that Brexit will cause an immediate implosion as to sever and annul existing co-operation between the other 27 member states. It is likely Brexit will cause a re-think of how the EU will operate in the future, but how that will be. nobody knows at present.

One of the many reasons for the formation of the EU was to seek co-operation among member-states in order to avoid further conflict. Two World Wars were fought on the continent in half a century. The cost of those conflicts are incalculable, as there is no price for the loss of human life.

The EU has morphed into its own structure, some arguing it replicates local government, but that is no more so than in federated nations like the USA or Australia, where two tiers of government at the state and federal level operate concurrently and often with competing and limiting powers. The EU has sought to operate on a communitarian approach, whereas Brexit is about separatism, hence the collision course.

Regardless of the path followed in the end, the UK is in for a rough economic ride in the immediate future. There is an anticipation of slower growth and reduced investment, no doubt contributed to by the vacuum and paralysis surrounding the implementation of Brexit, and the uncertainty of which options are best pursued.

It is difficult to see immediate solutions unfolding. Some will argue there is time, as after all there is a two year period after Article 50 has been invoked, during which the UK and the EU will negotiate and agree on the terms of Brexit. Those who argue this are probably unaware of the protracted negotiations required to reach an agreement on a simple bilateral basis, let alone a multi-party one. It is simply a matter of human functioning - the more people involved, the more difficult and longer the process. Just ask the Australians who have had to develop a range of negotiation skills in dealing with an explosion of FTAs in the past decade. The time taken to reach agreement is lengthy. As examples of FTAs between Australia and others: China FTA was the result of negotiations spanning a decade, Japan seven years and India so far 
five years, with no immediate result in sight. 35 These timelines are from the commencement of the process and do not reflect the diplomatic 'courting' that precedes the actual start of negotiations.

It is doubtful the UK would have an immediate group of public servants capable of meeting the Brexit challenge of negotiating a new FTA. This is because, so far, FTAs have been negotiated by the EU as a block and the UK would have no recent expertise to fall back on. In this respect they are at a disadvantage against their other EU counterparts.

The economic interdependence between the rest of EU and the UK, in the face of logic, would demand a win-win solution be found, but other forces are also at play. Some argue a soft exit would contribute to the dissolution of the EU as we know it now. In other words negotiations must be seen to be tough to discourage other would-be leavers. Yet pursuing a hard line may be synonymous with cutting your nose off to spite your face. The UK is a considerable importer of EU goods, a net importer indeed, so it would be of benefit to the other 27 member nations in total to ensure a win-win situation prevails.

Negotiating a less hardened solution may also avoid costly implementation resulting from additional customs checks, security considerations, documentation and supply chain delays, hardly ideal for exports or importers.

At present, one can only hope. The only certain thing about Brexit is its uncertainty, and uncertainty does not bode well for all concerned.

35 Department of Foreign Affairs and Trade, Status of FTA Negotiations, 8 August 2016, http://dfat.gov.au/trade/agreements/Pages/status-of-fta-negotiations.aspx, accessed 27 February 2017. 